\title{
Drug hypersensitivity syndrome induced by Beta-lectam and "Cold3" for the same patient
}

\author{
Ingrida Maciulaityte ${ }^{1^{*}}$, Simona Kasinskaite ${ }^{2}$, Kristina Bliudziute ${ }^{3}$, Violeta Kvedariene ${ }^{2}$ \\ From 6th Drug Hypersensitivity Meeting (DHM 6) \\ Bern, Switzerland. 9-12 April 2014
}

Drug hypersensitivity syndrome is difficult to diagnose, as many of its clinical features could imitate systemic disorders.

The aim of our study is to present the case of patient with drug hypersensitivity syndrome induced by two different kind of drugs in one year period.

A 65-year female took amoxicillin due to viral bronchitis. The second day 6-8 hours after applying the drug she developed generalized maculopapular egzanthema with itchiness. She was hospitalized in Vilnius University Hospital Santariskiu Klinikos because of progressive symptoms. The elevation of liver enzymes and discrasia were found. Specific IgE to amoxicillin, ampicillin, penicillin $\mathrm{G}$, penicillin $\mathrm{V}$ were negative. Symptoms completely disapeared after one month of treatment. After three months patch test with amoxicillin was carried out. 72 hours later the test was positive. Six months later patient was treated with "COLD3" (paracetamol, pseudoephedrine, dekstrametorfan), a cedar oil and homeopathic medications because of respiratory viral infection. The same day similar clinical picture appeared. Three month later we performed patch test with"COLD3", cedar oil and homeopathic drugs. Patch test with "COLD3", after 72 hours was positive and others - negative. Herpes simplex, EBV, CMV, and HBV, HCV were investigated and were negative.

\section{Conclusion}

Viral infection and hypersensitivity to drugs may induce drug hypersensitivity syndrome. It is essential to perform biochemical tests for patients presenting with a high fever and extensive skin rash after the intake of drugs.

Tilnius University, Lithuania

Full list of author information is available at the end of the article

\section{Authors' details}

${ }^{1}$ Vilnius University, Lithuania. ${ }^{2}$ Vilnius University, Center of Pulmonology and Allergology, Lithuania. ${ }^{3}$ Vilnius University, Center of Internal Medicine, Lithuania.

Published: 18 July 2014

\section{doi:10.1186/2045-7022-4-S3-P78}

Cite this article as: Maciulaityte et al:: Drug hypersensitivity syndrome induced by Beta-lectam and "Cold3" for the same patient. Clinical and Translational Allergy 2014 4(Suppl 3):P78.
Submit your next manuscript to BioMed Central and take full advantage of:

- Convenient online submission

- Thorough peer review

- No space constraints or color figure charges

- Immediate publication on acceptance

- Inclusion in PubMed, CAS, Scopus and Google Scholar

- Research which is freely available for redistribution
() Biomed Central

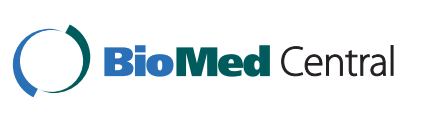

